\title{
The (Coming) Social Media Revolution in the Academy
}

\author{
Jessie Daniels, Joe R. Feagin
}

A revolution in academia is coming. New social media and other web technologies are transforming the way we, as academics, do our job. These technologies offer communication that is interactive, instantaneous, global, low-cost, and fully searchable, as well as platforms for connecting with other scholars everywhere.

\section{Scholarship: Knowledge Production and Use in a Networked Society}

Scholars now completing PhD's have likely never known a world without the Internet and social media. For them, GoogleScholar is where you go to begin a search for articles, not a brick-and-mortar library or its bound journals. For scholar-activists, social media offer additional promises of public sphere engagement with other specialists beyond one's discipline through blogs and Twitter. As barriers to long-distance travel increase, scholars are creating virtual conferences through digital video and web conferencing or follow conferences from afar via Twitter hashtags. For those who travel to conferences, backchannel Twitter communications can be important ways to extend the hallway conversations with colleagues. Scholars are experimenting with crowd-sourcing in ways that supplement old forms of peer-review. As publishing moves to ereaders, academic publishers face challenges to keep up with revolutionary changes.

Ultimately, this technological transformation is going to have major implications on expert knowledge. The Internet increases voices and knowledge available to all. Elitism in the expert knowledge world is declining; the Internet democratizes knowledge building and use. Much more knowledge has become available, and the distinction between experts and ordinary folks, what Gramsci might have called "organic intellectuals," is declining. However, new problems arise. The ability of those without critical-methodological training to deal with data smog (including fake, misinforming, and corporate-propaganda websites) is a serious barrier to peoples' understanding. Many Internet "analyses" remain superficial, even among supposedly expert analysts. The Internet provides the world with great new opportunities at democratization, open-source information and collaborative of scholarly knowledge production, while also containing serious, often hidden, pitfalls.

\section{Online Research in the Academy}

Now, academics do so much research online that it is difficult to remember a time when this wasn't the case. In the dark ages before the Internet, doing research involved a library, searching drawers of card catalogs and bound volumes, and reading hard-copies of printed books and journals. This was supplemented by searching microfilm of newspapers and magazines, and much standing over a copying machine. Today, much work of academics has been transformed. Young professors and graduate students go to libraries, but rather than look in card catalogs, they look at library computers and their own wifi-ed laptops. There are still books on shelves, but librarians tell us these are 
circulated less as use of online databases and electronic access to journals and ebooks continue to increase--often outstripping the cost of older library technologies.

Most information once available only in hard copy is now accessible for academics working away from their campus or college library. This opens up tremendous possibilities for working remotely, collaborating with colleagues globally, and being untethered to particular locations. In addition to databases indexing journal articles behind the library paywalls, research tools that index scholarly resources on the open web are widely used by academics. GoogleScholar and GoogleBooks are now part of the repertoire of many researchers.

\section{Academic Blogging and Microblogging}

Academics are increasingly bloggers. In many ways, this is a natural fit. Academics mostly love writing and blogging is, at its heart, an activity involving much writing. Academic blogging involves writing that is a remix of such items as a news story, an op-ed piece, and a critical review. Academic bloggers frequently use blogs to keep up with the relevant literature in their field, thereby providing a kind of public note-taking and research-sharing exercise. Academic bloggers also use blogging as a rough draft for ideas they later develop fully for peer-reviewed papers or books. (The second author has done exactly this for a new book, White Man's Party, on which he is currently working.) As they engage a wider audience beyond peers in their research subfield, academics' blogging can become scholar-activism. As Jennifer Ho remarks recently in the Journal of Women's History (Winter, 2010):

\footnotetext{
My initial blog entries were a form of pre-writing for my book chapters. Yet the sense of accountability that the blog inspired quickly grew beyond one of writing accountability to one of community accountability.... as I started to gather a group of readers beyond the friends and family in my address book, I began to see my blog writing as not merely free writing for my book but fundamental writing for issues about which I care deeply. And I began to see that my academic writing and my blog writing enrich and enhance one another; they both speak to the feminist ideals I believe in speaking truth to power and equality for all people.
}

Ho and other academic bloggers have embraced Internet technologies in ways that broaden the scope of their research work beyond college walls and in ways reaching beyond old disciplinary silos. This is partly about reaching audiences in disparate geographic locations, but more importantly it is about connecting with multiple publics with a shared interest across institutional and other social boundaries.

Micro-blogging, such as the highly popular Twitter, is a way to send short updates (140 characters or less) to a collection of individuals ("followers") that each user uses to their own liking. It seems surprising academics have taken to Twitter, given their deserved reputation for exceeding 140 characters, but they have. Academics, like others who use Twitter, have found short updates a useful way to find and maintain connections to others who share their research and other interests. While websites like Twitter can be accessed via desktop or laptop computer, they are also widely accessible via mobile devices, such as smart cellphones. Networking at academic conferences is no longer restricted to dull hallways of indistinguishable hotels, but simultaneously extended and constricted to fit within the short downtimes in any busy day. Time between classes means time enough to catch up on the interesting watercooler conversation about my research area of interest among a handful of people on Twitter. For academics who work in departments or institutions where few share their research interests, Twitter can be a useful way to expand one's intellectual impact and lessen intellectual isolation.

\section{| Virtual Conferences and Backchannels and Curating the Ideal Academic Department}

The virtual conference is another significant shift in how academics share their work. Recently, Jessie received the following invitation, via email:

This is a virtual conference, presenters are not required to physically travel to a conference location but instead provide their presentations to viewers online. It's completely free to submitters and viewers. The goal of the conference is to share the work being done...

While these are not yet commonplace, the prohibitive cost of much professional travel, and shrinking department 
budgets to cover travel, may speed more of such virtual sharing of research with colleagues. While invitation to a virtual conference is still unusual, academics still meet face-to-face at annual conferences which are also being transformed by digital technologies.

Backchannel communications between those attending in-person conferences help academics make connections in real time. Text messaging and Twitter and blog updates allow networks of academics to coordinate in-person connections. Backchannel communications also expand knowledge distribution. As one friend was sitting in a conference session Jessie could not attend, she could read her Twitter updates about key research presented at that session.

For academics that may toil in relative isolation from others who share their immediate interests, the social connection of blogging and microblogging can also provide an opportunity to curate the ideal academic department. While in another era, scholars may have identified strongly with their PhD-granting university, the college or university, or the academic department in which they are currently employed, the rise of social media allows for a new arrangement of colleagues. Scholars now have conversations via Twitter, Facebook and blogs that maintain close collegial ties with others who share their scholarly interests even though they may not share an institutional home or the same academic department. Today, rather than being restricted to the colleagues one finds in ones' own department, scholars (and teachers) go online to find intellectual companionship, in effect, curating the ideal academic department and tailoring it to their interests.

\section{| Open Peer-Review \& Crowd-Sourced Edited Volumes}

The open source movement has broad implications for higher education and the work academics do. While one early experiment in open-review at the journal Nature is regarded as a failure [1], there is a new attempt by Elsevier to launch an open-review system. Whether Elsevier's effort will succeed remains to be seen, but there are now numerous examples of post-publication peer review that appear to out-perform traditional pre-publication peer review, especially in the natural sciences. In summer 2010 a research paper published in Science claimed to have identified genes associated with longevity with " $77 \%$ accuracy"; it soon received a detailed and devastating postpublication review from the Google-owned DNA service, 23andme. This review was followed by detailed critiques from other science bloggers. [2] The future many academics in the natural and other sciences envision is one where post-publication peer review dominates scholarly publication, with little or no pre-publication review necessary.

Crowd-sourcing, the concept that an open call to an undefined group of people will gather those best able to contribute with relevant and fresh ideas, is one that is appealing to many and could have interesting implications for the work academics do. In May 2010, academics Dan Cohen and Tom Scheinfeldt launched an exciting experiment they called "Hacking the Academy." Their idea was to crowd source an edited volume about new approaches to higher education in one week. They asked potential contributors to consider questions like: Can an algorithm edit a journal? Can a library exist without books? Can students build their learning management platforms? Can a conference be held without a program? Can Twitter replace a scholarly society? In keeping with the spirit of "hacking" in which they reimagined the edited volume, Cohen and Scheinfeldt devised this strategy:

"Any blog post, video response, or other media created for the volume and tweeted (or tagged) with the hashtag \#hackacad will be aggregated at hackingtheacademy.org (submissions should use a secondary tag — \#class \#society \#conf \#journal \#book \#tenure \#cv \#dept \#edtech \#library — to designate chapters). The best pieces will go into the published volume. The volume will also include responses such as blog comments and tweets to individual pieces.’’[3]

\section{Academic Publishers Confront E-Publishing, and E-Reading}

Since 2005 the explosive growth of dramatic new publishing technologies is revolutionizing creation of and access to books. Millions of ebooks, earticles, and ereaders have created major challenges for academics and academic publishers. Publishers have seen ebooks increase to 10-20 percent of total sales, and the number of one major ereader, the Kindle, is now more than 8 million. Millions of other ereaders have also been sold.

Ereaders are lightweight, hold thousands of books, and can be carried almost anywhere. They allow people to 
read articles and books when they want, at larger fonts, with easy notetaking. They allow for nearly instantaneous downloads of hundreds of thousands of books. (Articles on the epublishing revolution can be found daily at www. teleread.com).

In a recent interview, Clay Shirky, prominent Internet and ebook technology analyst, asks a critical question: Who will vet for academic and other readers the billions of new books and articles that will explode across epublishing websites. [4] Now publishers provide critical editorial work that makes for strong books. Without that editing and other publishers' value-added work, most books would be, as one editor put it to us, just “junk." Self-publishing on the web and other web-publishing mostly leaves out critical editorial revising and copyediting. For the billions of publications soon to be epublished, new software and vetting websites will be required to edit and polish publications for academic writers and to evaluate these new epublications for quality for academic readers.

The web cannot do this yet, and the visibility they generate for ebooks is not what counts, but the reliability and worth of who says something is worth reading.

Some existing paper book publishers are getting into epublishing with innovative new projects, such as the joint hardback/ebook series of short social science books under the editorship of Ben Agger and Steve Rutter at Routledge. This hardback part involves print-on-demand technology of (POD), which integrates traditional pulp publishing with Internet ordering. Cautiously, but actively, publishers will likely couple new epublishing ideas to their old tested models. Ebooks have the huge advantage of being fully searchable, more portable, and link-filled to other media and sources.

Web epublishing has also opened up much larger and global audiences for articles. One U.S. social science ejournal started by a sociologist, Fast Capitalism, get hundreds of thousands of monthly readers and much global visibility for authors and journal, including many submissions from researchers overseas. In creating online journals, the humanities are currently well ahead of the social science, but in the near future we predict that most social science journals will be ejournals (the ASR is already readable online).

These technological developments have serious implications for the academic enterprise. We only have room to list a few other issues: Ebook retailers often price serious academic books too low for them to be viable for publishers and authors. Until someone works out how to financially support serious academic book publishing ebooks available and on the web, we may see less serious academic publishers disappearing and fewer serious research efforts in book form. Online piracy of earticles and ebooks is skyrocketing, raising again the same question of academic ebook viability.

\section{| Digital Humanities but No Digital Sociology}

All these changes in scholarship have been taken up with a great deal more enthusiasm by some in the academy than others. Our colleagues in the humanities have embraced digital technologies much more readily than those of us in sociology or the social sciences more generally. A casual survey of the blogosphere reveals that those in the humanities (and law schools) are much more likely to maintain academic blogs than social scientists. In terms of scholarship, humanities scholars have been, for more than ten years, innovating ways to combine traditional scholarship with digital technologies. To name just a two examples, scholars in English have established a searchable online database of the papers of Emily Dickinson and historians have developed a site that offers a 3D digital model showing the urban development of ancient Rome in A.D. 320. There are significant institutions being built in the digital humanities including the annual Digital Humanities Conference, which began in 1989, and the National Endowment for the Humanities' Office of Digital Humanities.

Sociology lags far behind in the adoption of digital tools for scholarly work. As Paul DiMaggio and colleagues noted in 2001, "sociologists have been slow to take up the study of the Internet" ("The Social Implications of the Internet," Annual Review of Sociology, 2001, p.1). While there are notable exceptions, such as Andrew Beveridge's digitizing of Census maps (www.socialexplorer.com), when looking at the field as a whole these sorts of innovations are rare in sociology. In contrast to the decade-long conference in the digital humanities, there is no annual conference on "digital sociology." Sociology graduate students Nathan Jurgensen and PJ Rey recently organized a conference on "Theorizing the Web," that drew luminaries in sociology Saskia Sassen and George Ritzer, but this is the first sociology conference (that we are aware of) to focus exclusively on understanding the digital era from a sociological perspective. Analogously, there is no large institution, like the NEH seeking to fund digitally informed sociological research. The reasons for this sociological lag when it comes to the Internet are still not clear, but some point to the 
problems of getting digital publication projects recognized by tenure and promotion review committees.

\section{Implications for Hiring, Promotion and Tenure}

Scholars across disciplines often express reservations about the use of social media as a "waste of time" or a "distraction" that takes them away from their academic pursuits. Christine Hurt and Tung Yin refer to blogging without tenure as "an extreme sport" because of the risks involved (2006, p. 1235). They enumerate these risks of blogging for untenured faculty as including: the amount of time involved, being controversial, being wrong, and sharing too much personal information. These are all legitimate concerns that any blogger (not just an academic) should weigh in the balance before engaging with social media.

However, our experience with our academic blog (www.racismreview.com) has been quite the opposite of these pitfalls. Since we started the blog in 2007, a dozen or more junior faculty and graduate students have served as guest bloggers for us. These guest bloggers typically write about their own research and use the blog to reach a wider audience, which may include potential employers. It is now commonplace for graduate students' guest blog stints to appear on academic CV's or in cover letters for academic positions. How these end up being evaluated by hiring committees remains an open question.

When it comes to promotion and tenure, the recognition of the digital production of knowledge is still not uniformly recognized across institutions or disciplines. There are a variety of mechanisms within existing structures that could allow for the recognition of this sort of knowledge production. For instance, some institutions allow for a category known as “creative works in one's discipline." Originally intended to include works in fine or performing arts like interpretive dance, music scores or paintings, this category is expanding to include digital works of scholarship as "creative." At other institutions, there is a category of work considered for promotion and tenure called "dissemination of research," typically used to include public speaking or letters to the editor of newspapers. Increasingly, this is being adapted to include digital works. And most institutions have a "service" category that could also be expanded to include the digital production of knowledge, such as academic blogging. One thing is certain, as more and more scholars take up digital practices that expand their academic work, they will begin to expect that this work be taken much more seriously by hiring, promotion and tenure committees.

\section{Implications for the Meaning of Expert Knowledge}

The Internet has had a democratizing effect on expertise. One scholar referred to it as expertise as a "withered paradigm" given the web (Walsh, 2003). Concepts that once may have seemed an agreed upon cultural value, like "equality" and "objectivity" are now fought over online in ways unimagined previously. Similarly, concepts that have the weight of considerable scientific evidence behind them, such as global warming, become contested by climate change deniers. One especially pernicious way that the Internet challenges the notion of expertise is through the proliferation of hard-to-detect propaganda, much of it funded by wealthy arch-conservatives. For instance, the emergence of cloaked websites that disguise authorship in order to conceal a political agenda can be very confusing. The "California Latino Water Coalition" appears to be a grassroots organizing effort to stop the corporate control of the water supply, but it is in fact a front group for corporate agribusiness. A casual web user would never know this from the URL LatinoWater.com, without a visit to an additional site such as Internic WhoIS or SourceWatch. The presence of intentionally disguised propaganda online, along with the challenge to expertise brought on by the democratizing of the web, means that what we say we know is a constantly contested political terrain. The evaluation of expertise in this new online environment often has more to do with good graphic design than with the text-based content.

\section{Conclusion}

For some, the revolution is already here. The increasingly digital, geographically distributed nature of the work academics do opens up exciting new possibilities for research, collaboration and an open-source approach to peer- 
review, knowledge production and dissemination. For scholar-activists, the web creates new avenues for engaging with wider publics. Yet, the expanding, and radically democratized audience also challenges old paradigms of expertise. The democratizing influence of the Internet also has serious implications for expertise and how we evaluate expert knowledge claims.

\section{Endnotes}

1. See the discussion here: http://www.nature.com/ nature/peerreview/debate/nature05535.html .

2. See the discussion here: http://cameronneylon. net/blog/p-\%E2\%89\%A0-np-and-the-future-of-peerreview/

3. See the description here: http://hackingtheacademy. org/what-this-is-and-how-to-contribute/.

4. http://bnreview.barnesandnoble.com/t5/Interview/ Clay-Shirky/ba-p/2880

\section{References}

Castells, Manuel. 2003. The Internet Galaxy: Reflections on Internet, Business and Society. (New York: Oxford University Press).

Cohen, Dan. 2004. "History and the Second Decade of the Web," Rethinking History Vol. 8, (2):293-301.

Halavais, Alexander. 2006. "Scholarly Blogging: Moving toward the Visible College," A. Bruns and J. Jacobs (Eds.), Uses of Blogs, (New York: Peter Lang).

Hurt, Christine and Tung Yin. 2006. "Blogging While Untenured and Other Extreme Sports," Washington University Law Review (84): 1235-55.

Kamenetz, Anya. 2010. DIY U: Edupunks, Edupreneurs, and the Coming Transformation of Higher Education. (San Francisco: Berrett-Koehler Publishers).

Rheingold, Howard. 2002. Smart Mobs: The Next Social Revolution. (New York: Basic Books).

Shenk, David. 1997. Data Smog: How to Cope with the Information Glut. (New York: HarperCollins). And, see also, the author's review of his predictions 10 years later: http:// www.slate.com/id/2171128/.

Solum, Lawrence B. 2006. "Blogging and the Transformation of Legal Scholarship," Washington University Law Review (84):1071-88 .
Vaidhyanathan, Siva. 2011. The Googlization of Everything: And Why We Should Worry. Berkeley, CA: University of California Press.

Walker, Jill. 2006. "Blogging from Inside the Ivory Tower," in A. Bruns and J. Jacobs (Eds.), Uses of Blogs, (New York: Peter Lang).

Walsh, Peter. 2003. "That Withered Paradigm: the Web, the Expert and the Information Hegemony," MIT Communications Forum, http://web.mit.edu/comm-forum/ papers/walsh.html.

Wellman, Barry and Carolyn A. Haythornthwaite, (Eds.). 2002. The Internet in Everyday Life. (Malden, MA.: Blackwell). 